\title{
Bioremediation of actual soil samples with high levels of crude oil using a bacterial consortium isolated from two polluted sites: investigation of the survival of the bacteria
}

\author{
Samarghandi M.R. ${ }^{1}$, Arabestani M.R. ${ }^{2}$, Zafari D. ${ }^{3}$, Rahmani A.R. ${ }^{1}$, Afkhami A. ${ }^{4}$ and Godini K. ${ }^{1,}$ \\ ${ }^{1}$ Department of Environmental Health Engineering, Faculty of Health and Research Center for Health Sciences, Hamadan University of \\ Medical Sciences, Hamadan, Iran. \\ ${ }^{2}$ Nutrition Research Center, Hamadan University of Medical Sciences, Hamadan Iran \\ ${ }^{3}$ Department of Plant Protection, Faculty of Agriculture, University of Bu-Ali Sina, Hamadan, Iran \\ ${ }^{4}$ Department of Analytical Chemistry, Bu-Ali Sina University, Hamadan, Iran \\ Received: 14/03/2018, Accepted: 30/05/2018, Available online: 13/09/2018 \\ *to whom all correspondence should be addressed: e-mail: kgoodini@razi.tums.ac.ir
}

\begin{abstract}
In this study, actual soil samples, taken from Kharg Island, Iran, with high levels of total petroleum hydrocarbons (TPHs) were bioremediated by a bacterial consortium. The strains were: Pseudomonas sp., Stenotrophomonas sp., Achromobacter sp., Brevibacillus sp. and Staphylococcus sp., which were isolated from two highly polluted sites: Kharg Island and Kermanshah Oil Refinery. The bacteria were identified and confirmed by biochemical tests and the PCR assay. In order to isolate the bacteria, the enrichment method, in which crude oil (2\%) was utilized as the sole source of carbon and energy, was used. The results showed that the adapted bacterial consortium could degrade nearly $60 \%$ of the pollution. Also, it was found that after 100 days of bioremediation only Brevibacillus sp. could survive in the environment.
\end{abstract}

Keywords: Bioaugmentation, Pseudomonas sp., Petroleum hydrocarbons, Contaminated soil

\section{Introduction}

The environment may be contaminated through releasing petroleum components because of crude oil exploration, accidents, transportation, and leakage from waste disposal or storage sites, or from industrial facilities (Almasi et al., 2016). These substances are comprised of various compounds as follows: alkanes, light aromatics (MAHs), cycloalkanes, heavy aromatics (PAHs) and asphaltenes, and so forth, some of which are mutagenic and carcinogenic (Timmis et al., 2010). Bioremediation, which uses microorganisms able to decompose pollutants from contaminated soils, is a clean, cost-effective and environmentally friendly approach and, more importantly, it reaches a complete degradation of pollutants in spite of other methods leaving toxic secondary by-products (Koolivand et al., 2017; Aljuboury et al., 2017). Apparently, a single bacterium or microorganism cannot biodegrade well contaminants like crude oil containing enormous compounds as usually a wide range of petroleum hydrocarbons are not decontaminated by one microorganism (Mishra et al., 2001). Since actual environments like polluted soils, dislike synthetic solutions, are not homogenous and include different kinds of pollutants, the application of mixed microbial populations or consortia, which are comprised of enzymatic traits, often results in by far better results (Mishra et al., 2001). Moreover, it can be claimed that each strain can use a certain substrate as its source of carbon and energy. It has even been reported that, when the strain uses the compounds from crude oil, the residual combinations back the growth of other strains in soil (Horowitz et al., 1975). Thus, different mixtures of bacterial or bacterial-fungal cultures have been utilized in order to clean up effectively contaminated soil with petroleum compounds (Bagherzadeh-Namazi et al., 2008; Ghazali et al., 2004; Rahman et al., 2002). For instance, Poi et al. employed an adapted indigenous consortium consisting of 22 strains: mainly Bacillus, Pseudomonas and Acinetobacter spp. in a large scale bioaugmentation system for clean-up of soil contaminated with petroleum hydrocarbons; they concluded that this system constitutes a proper method for the treatment of full-scale petroleum polluted soil (Poi et al., 2017). It is entirely clear that the main upside of using a consortium, instead of a single microorganism, is its synergistic effect, because one species degrades toxic metabolites, which may hinder the growth of other strains and, in turn, this collective system promotes the bioremediation process (Ghazali et al., 2004). Also, indigenous bacterial strains applied in a consortium can better tolerate toxic petroleum compounds and, more importantly, resist environmental changes (Mishra et al., 2001; Eriksson et al., 1999; Dibble and Bartha, 1979).

Further, since field scale conditions and actual samples usually contain different kinds of pollution like crude oil and all these pollutants are not biodegraded 
simultaneously and also the number of bacterial population during the process should not be less than $10^{3}$ to be effective, the survival and monitoring of microorganisms are of great importance; for example, multi-ringed aromatic hydrocarbons are not decomposed over the early phases of bioremediation processes (Lal and Khanna, 1996; Ramos et al., 1991; Song et al., 1990). The prime objective of the current research was to evaluate the ability of a bacterial consortium comprised of new strains isolated from two oil industrial sites in cleanup of actual samples of contaminated soil with petroleum hydrocarbons. Further, during the process, the survival of the strains was assessed.

\section{Materials and methods}

\subsection{Site description and Soil sampling}

The bacterial strains were isolated from the samples taken from two petroleum sites: Kharg Island $\left(29^{\circ} 14^{\prime} 26^{\prime \prime} \mathrm{N}\right.$ $\left.50^{\circ} 18^{\prime} 33^{\prime \prime} \mathrm{E} 35 \mathrm{~km}\right)$ and Kermanshah Oil Refinery $\left(34^{\circ} 21^{\prime} 04^{\prime \prime} \mathrm{N} 47^{\circ} 06^{\prime} 12^{\prime} 12^{\prime \prime} \mathrm{E} 3 \mathrm{~km}\right)$. These two sites are known in terms of high volume of petroleum activities. The first one is one of the most important sites for oil exportation in Iran and the latter is one of the largest refineries as it produces 30000 barrels of oil per day. The samples were taken randomly from the contaminated soils of these two sites. All the soil samples collected in sterilized seal pack polythene bags and then ground and sieved through a $2 \mathrm{~mm}$ pore size sieve to improve homogeneity and kept at $4{ }^{\circ} \mathrm{C}$ for less than $48 \mathrm{~h}$ before bacterial examination. In the present study, the bioremediation runs were conducted on the samples taken from Kharg Island; these samples thus were tested to measure the following parameters: $\mathrm{pH}$, potassium, phosphorus content, soil tissue, moisture content and electroconductivity. EC and $\mathrm{pH}$ were determined by a lab conductivity meter and $\mathrm{pH}$ meter ( $\mathrm{HACH} \mathrm{CO})$, respectively. Moisture contents were gravimetrically detected by means of a vacuum oven at 70 ${ }^{\circ} \mathrm{C}$ for $48 \mathrm{~h}$. Total nitrogen and phosphorus concentrations were measured by the Kjeldahl method and spectrophotometrically (4500-PC), respectively. The content of potassium was measured by the standard method (Wilke, 2005) and the contents of total petroleum hydrocarbons (TPHs) were detected by gas chromatography (GC). The properties of the sampled soils were as follows: $\mathrm{pH} 6.5-7, \mathrm{~K} 293.16 \mathrm{mg} / \mathrm{kg}, \mathrm{P} 30 \mathrm{mg} / \mathrm{kg}$, tissue sandy loam, TPH 600-13000 mg/L, EC $0.0391 \mathrm{mS} / \mathrm{cm}$ and CFU/g 200-500.

\subsection{TPH analysis}

First, the extraction of TPH from the soil was carried out via the liquid-liquid extraction way in two phases by $5 \mathrm{~mL}$ of $\mathrm{n}$ hexane. Next, the obtained extracts were dewatered by activated sodium sulfate. Then, they were dried by flowing nitrogen gas and obtain special volumes. At this time, they were prepared to be injected to the GC device (GC-2010, Shimadzu, Japan) equipped with a hydrogen flame ionization detector (FID) and $25 \mathrm{~m}$ long SGE capillary column (fused silica, film thickness: $0.25 \mu \mathrm{m}$, ID: $0.22 \mathrm{~mm}$ ). In this study, the carrier gas was helium applied at the rate of $2.9 \mathrm{ml} \mathrm{min}^{-1}$. The initial temperature was kept at $35{ }^{\circ} \mathrm{C}$ for $2 \mathrm{~min}$ and then it was raised at the rate of $10^{\circ} \mathrm{C} \mathrm{min}-1$ to reach $300{ }^{\circ} \mathrm{C}$ and maintained constant for $5 \mathrm{~min}$. For cleaning the column, the final temperature was set at 325 ${ }^{\circ} \mathrm{C}$ for $5 \mathrm{~min}$. The actual pressure and split ratio were $11 \mathrm{psi}$ and $25 \%$, respectively. The flow rates of hydrogen gas, air, and makeup for FID were 40, 450, and $30 \mathrm{ml} \mathrm{min}^{-1}$, respectively.

\subsection{Culture Medium}

Bushnell-Haas $(\mathrm{BH})$ broth, which is a mineral salt medium, was used in the current study; the medium was comprised of: $1 \mathrm{~g} / \mathrm{L} \mathrm{KH}_{2} \mathrm{PO}_{4}, 1 \mathrm{~g} / \mathrm{L} \mathrm{K}_{2} \mathrm{HPO}_{4}, 1 \mathrm{~g} / \mathrm{L} \mathrm{NH}_{4} \mathrm{NO}_{3}, 0.2 \mathrm{~g} / \mathrm{L} \mathrm{CaCl}_{2} \bullet$ $7 \mathrm{H}_{2} \mathrm{O}$, and $0.2 \mathrm{~g} / \mathrm{L} \mathrm{MgSO}_{4} \bullet 7 \mathrm{H}_{2} \mathrm{O}$. The $\mathrm{pH}$ of the culture was adjusted at 7.0 and then sterilized via autoclaving at $121^{\circ} \mathrm{C}$ for $20 \mathrm{~min}$ before application. Moreover, in this research crude oil was utilized as the sole carbon and energy source in order to enrich and isolate the strains having the ability to degrade petroleum hydrocarbons.

\subsection{Isolation and screening of strains}

Ten $\mathrm{g}$ of the contaminated soil sample was added into 200 $\mathrm{mL}$ of the $\mathrm{BH}$ medium containing $20 \mathrm{~g} / \mathrm{L}$ of the crude oil as the sole carbon and energy source. The culture was incubated in a rotatory shaker $(150 \mathrm{rpm})$ under sterile conditions at $37{ }^{\circ} \mathrm{C}$ for $7 \mathrm{~d}$. Afterwards $100 \mu \mathrm{L}$ of the incubated culture was added to the fresh solution of the $\mathrm{BH}$ culture containing $20 \mathrm{~g} / \mathrm{L}$ of the crude oil. This inoculation was repeated consecutively three times (under the same conditions). It should be pointed that the procedure was lasted for 4 weeks. After enrichment, $10 \mu \mathrm{L}$ of the final incubated culture was spread on the nutrient-agar plates (containing $10 \mathrm{~g} / \mathrm{L}$ crude oil) and then incubated at $37^{\circ} \mathrm{C}$ for 24-48 h. Following, grown single and pure colonies were cultured separately on the fresh plates and reincubated for 24-48 h. At this stage, the isolated colonies were picked from the plates and stored in beef extract peptone medium (BEPM), with $15 \%(\mathrm{w} / \mathrm{w})$ glycerol at $-80^{\circ} \mathrm{C}$, until they were used. Finally, the isolates were first assessed according to the morphological, cultural characteristics of each colony, followed by routine biochemical tests.

\subsection{DNA extraction and isolate confirmation by the $P C R$ assay and sequencing}

In this study, DNA extraction was performed through the thermal lysis (boiling method) (El Aila et al., 2009) with some modifications. First, $400 \mu \mathrm{L}$ of ice-cold ethanol was added into the micro tube containing nucleic acid so as to concentrate the nucleic acid attain from the thermal lysis. Next, the solution was mildly mixed and kept in a deep freezer $\left(-18\right.$ to $\left.-20^{\circ} \mathrm{C}\right)$ for $10-30 \mathrm{~min}$. Afterwards, it was centrifuged for $10 \mathrm{~min}$ at the maximum speed of $4000 \mathrm{rpm}$. At this stage, the supernatant was removed and the pellet was dried out fully by means of the heater block (Nedaye Fan Co., Iran) at $55{ }^{\circ} \mathrm{C}$. Finally, $50 \mu \mathrm{L}$ of sterile $1 \mathrm{x}$ TE [TrisEDTA buffer] buffer was poured to the micro tube and the pellet was mildly dissolved. A few of the concentrated nucleic acids were used for PCR and the rest were saved frozen at $-20^{\circ} \mathrm{C}$ for future applications.

In order to confirm the extracted isolates detected by phenotypic methods, the PCR assay was applied and the 
reaction was done using Bio-Rad Thermal Cycler; thus, so as to amplify the $16 \mathrm{~S}$ rRNA gene the primer $8 \mathrm{~F}$ (forward $-5^{\prime}$ GGATTAGATACCCTGGTAGTCC-3' and reverse-5'TCGTTGCGGGACTTAACCCAAC-3'). The PCR mix contained 1 $\mu \mathrm{L}$ (10 pmol) of the primer, $2 \mu \mathrm{L}$ DNA, $12.5 \mu \mathrm{L}$ PCR Master Mix in a final $25 \mu \mathrm{L}$ reaction volume. DNA amplification was conducted in a thermal cycler (S1000 ${ }^{\mathrm{TM}}$ Thermal Cycler, BioRad, Hercules, CA, USA), under the following conditions: initial denaturation at $95{ }^{\circ} \mathrm{C}$ for $5 \mathrm{~min}$, followed by 35 cycles of denaturation at $95{ }^{\circ} \mathrm{C}$ for $1 \mathrm{~min}$, an annealing temperature at $57{ }^{\circ} \mathrm{C}$ for $1 \mathrm{~min}$, an extension at $72{ }^{\circ} \mathrm{C}$ for 1 min, followed by a final extension at $72{ }^{\circ} \mathrm{C}$ for $5 \mathrm{~min}$. Electrophoresis of the amplified DNA fragments, along with a 100 bp DNA ladder, was carried out using $2 \%$ agarose gel (Merck, Darmstadt,- Germany).

One sample of each PCR products (amplicons) was sequenced by Bioneer Co., Korea mediated by Pishgam Co., Iran and the data were analyzed using the Chromas software and aligned with the ClustalW program. Sequences were compared to those present in the databank using blast and aligned with the ClustalW program.

\subsection{Comparison of the growth rates of the isolated strains Microbial monitoring}

All the isolated strains were cultured on the nutrient-agar plates for 24-48 $\mathrm{h}$ for growing pure colonies. Then, the grown colonies of each strain were dissolved into $10 \mathrm{~mL}$ of distilled water to increase turbidity stemming from the growth of bacteria by its optical densities (OD) at the wavelength of 600 reached 0.5 McFarland standard $\left(1.5 \times 10^{8} \mathrm{CFU} \mathrm{mL} \mathrm{m}^{-1}\right)$. Next, these solutions were added to $100 \mathrm{~mL}$ of the sterilized $\mathrm{BH}$ culture and then incubated in a shaking incubator at $37{ }^{\circ} \mathrm{C}$ for 30 days. The growth rates of all strains were assessed and compared daily over the treatment by means of their levels of $\mathrm{OD}_{600}$. It should be noted that a separate $100 \mathrm{BH}$ culture without any strain was considered as the control sample and its $\mathrm{OD}_{600}$ was monitored during the period.

\subsection{Strain selection and bioremediation runs (inoculation)}

The consortium applied in this study consisted of 9 isolated bacterial strains. The basis of the bacterial selection was the growth rate of the isolated strains in $\mathrm{BH}$ containing $2 \%$ of crude oil as the sole source of carbon and energy. At this stage, so as to prepare the samples (500 g of the polluted soil each) with a standard inoculation (at least $10^{6}$

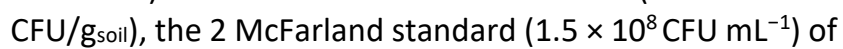
each strain was prepared as each bacterium was grown on Tryptone Soy Broth at $37^{\circ} \mathrm{C}$ in an orbital shaker at $150 \mathrm{rpm}$ for $24 \mathrm{~h}$ to reach the enough number of each cell. Then, a consortium comprised of all strains with $\mathrm{OD}_{600}$ of 2 McFarland was prepared and was added to the soil samples $(10 \%(v / w))$. It should be noted that the TPH concentration range of the sample soil was between 600 and $1300 \mathrm{mg} / \mathrm{L}$. In the current research, two kinds of experiments containing $500 \mathrm{~g}$ of the soil samples: sterilized (autoclaved) and unsterilized were utilized to evaluate the impact of the addition of the inoculation. It should be pointed that each experiment was performed in triplicate and mean values of data were reported.

Table 1. Identification and characterization of the strains isolated from the soil of Kharg Island

\begin{tabular}{|c|c|c|c|c|}
\hline Strain & Closet relatives & Phylogenetic group & Similarity (\%) & $\begin{array}{c}\text { Accession no. of } \\
\text { closet relatives }\end{array}$ \\
\hline 1 & Stenotrophomonas acidaminiphila & Y-Proteobacteria & 99 & CP019797 \\
\hline 2 & Achromobacter sp. strain TPKDS1 & $\beta$-Proteobacteria & 99 & KX984042 \\
\hline 3 & Pseudomonas sp. strain DNE-S1 & Y-Proteobacteria & 95 & MF803832 \\
\hline 4 & Stenotrophomonas rhizophila strain MA-25 & Y-Proteobacteria & 99 & KX426625 \\
\hline 5 & Achromobacter pulmonis strain R-16442 U-SMWF-Al2 & $\beta$-Proteobacteria & 97 & KX778109 \\
\hline 6 & Brevibacillus sp. NCCP-1139 & Firmicutes & 98 & LC065166 \\
\hline 7 & Pseudomonas aeruginosa strain 1242 & Y-Proteobacteria & 96 & MF574356 \\
\hline 8 & Pseudomonas sp. BJ-27 & Y-Proteobacteria & 94 & GQ280037 \\
\hline 9 & Staphylococcus arlettae strain LEH4_3A & Firmicutes & 98 & JN644587 \\
\hline
\end{tabular}

\section{Results and discussion}

The GC analysis showed that the soil contained normal alkanes (hydrocarbons from C12-C29). It illustrates that the pollution is of aged petroleum hydrocarbons because alkanes (C4-C11) are disappeared for evaporation (Figure 4).

All bacterial strains were identified by the biochemical tests and were confirmed using the PCR assay (Fig. 1). Nine strains of bacteria capable of growing in mineral salt broth containing $2 \%$ of the crude oil, as the sole source of carbon and energy. The strains were Gram-negative and positive and oxidase positive and negative with a predominance of Proteobacteria (approximately 78\%). The findings of the $16 \mathrm{~S}$ rRNA sequences of the isolated bacteria showed that the rest were affiliated to the Firmicutes (Table 1). Also, the Gamma and Beta subclasses of Proteobacteria were represented by 5 and 2 isolates, respectively. It is known that the Gamma subclass of the Proteobacteria and Firmicutes have this property to generate producing catabolic enzymes, by which petroleum hydrocarbons can be degraded (Nnamchi et al., 2006); moreover, these bacteria can be adapted in extreme environments such as soils, sediments and sludge contaminated with high levels of pollution via coincidental induction of a few catabolic pathways, resulting in reaching new ways for biodecomposition of different contaminants (Ornston and Yeh, 1982). For instance, Whyte et al. explained that a transfer of biodegradative pathways between mesophiles and psychrotrophs in nature may be a reason for the similar 
alk pathways (C5-C12 n-alkanes) of mesophilic $P$. oleovorans and two hydrocarbon-degrading psychrotrophic Pseudomonas spp. strains, isolated from petroleum-contaminated Arctic soil (Whyte et al., 1996). All 19 strains isolated in this study were able to grow in $\mathrm{BH}$ medium containing $2 \%$ of crude oil as the sole carbon and energy; in general, nine strains showed the highest growth rates $\left(O D_{600}=0.2-0.9\right)$. Figure 1 indicates a mixed model of the growth rates of the strains isolated.

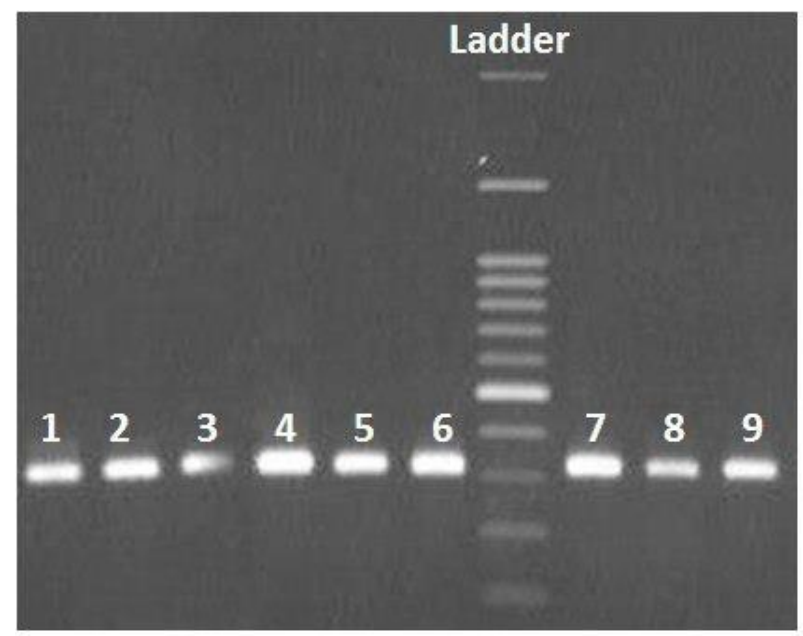

Figure 1. Agarose gel electrophoresis analysis of 16S rRNA gene amplified from nine bacterial isolates. PCR amplified products were run on $1 \%$ agarose gel. Lane $M$ indicates the DNA ladder (O'GeneRuler DNA Ladder Mix 320 base pair, catalogue number SM1173, ThermoFisher). Markers with high intensity have been presented by their size. Lanes 1 to 9 show the PCR amplified 16S rRNA gene of the respective bacterial isolates.

The review of literatures reveals that consortium containing bacterial strains are capable of degrading crude oil (El Mahdi et al., 2016). However, since the environment may often be contaminated by different kinds of hydrocarbon pollutants like crude oil comprised of different kinds of compounds, a single bacterium cannot use all hydrocarbons as its substrate to grow and, in turn, degrade them (Couling et al., 2010). The consortium applied in the present study were selected from the genera Pseudomonas (3 strains), Achromobacter (2 strains), Stenotrophomonas (2 strains), Staphylococcus (1 strain), and Brevibacillus (1 strain). In accordance with our study, other researchers have reported similar results; for example, Fallgren and Jin utilized a bacterial consortium comprised of Pseudomonas, Achromobacter, Bacillus and Micromonospora genera (Fallgren and Jin, 2008). And, Arvanitis et al. claimed that Acinetobacter and Rhodococcus strains can be employed in consortium as their ability in petroleum hydrocarbon degradation (Arvanitis et al., 2008). Interestingly, Pseudomonas aeruginosa strain 1242 was isolated from the polluted site of Kharg Island; this species is a typical strain for the production of rhamnolipid, which can improve the bioavailability in soil, and can consume crude oil as the sole carbon and energy source. It should be noted, besides Pseudomonas species, all other strains isolated in the current research were able to tolerate high levels of crude oil.

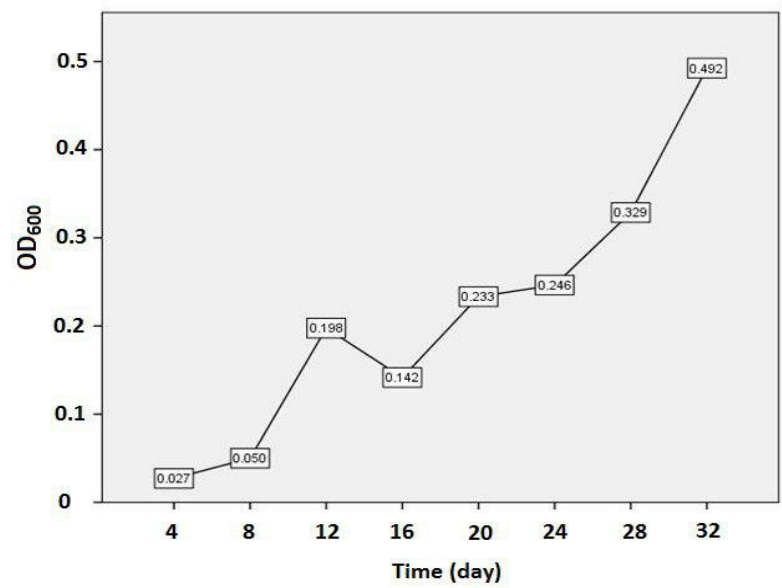

Figure 2. The mixed model of the growth rates of the strains isolated.

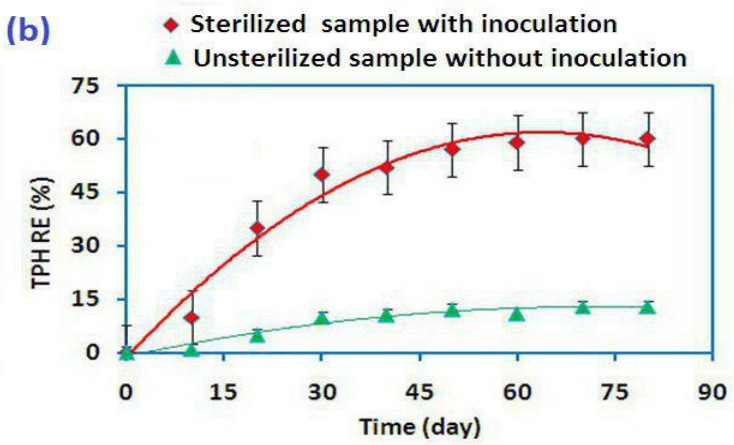

Figure 3. (a) The growth rates in sterilized soil sample with inoculation and unsterilized soil sample without inoculation and (b) Trend of TPH removal in sterilized soil sample with inoculation and unsterilized soil sample without inoculation 

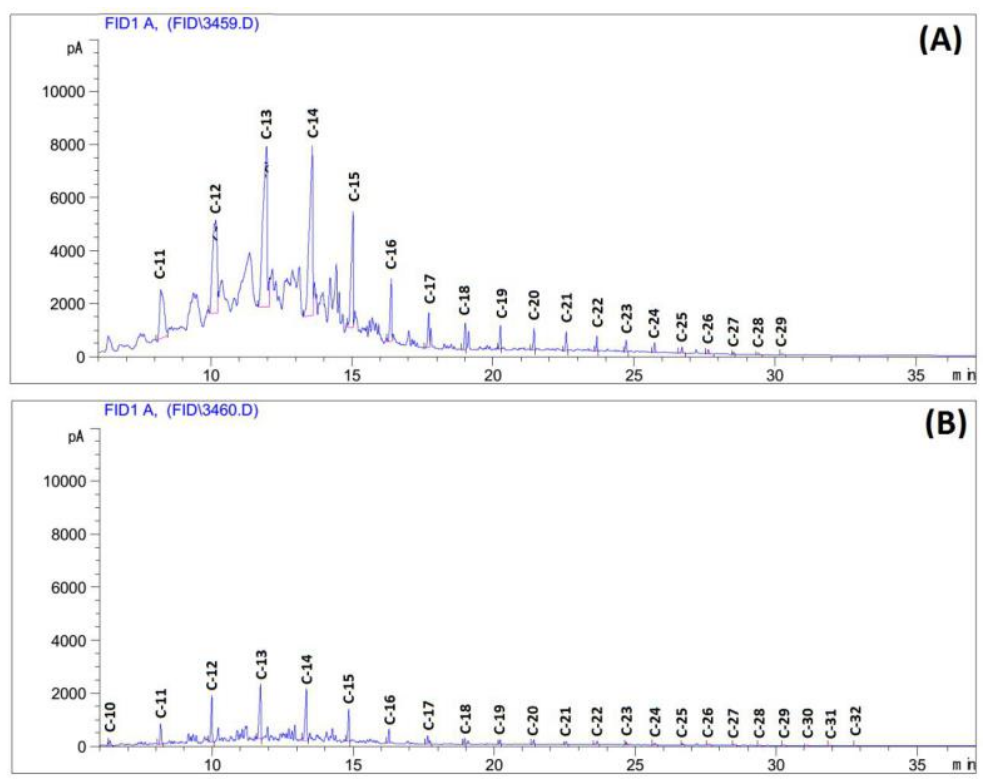

Figure 4. Gas chromatography analysis of petroleum compounds $(A)$ before and $(B)$ after the bioremediation process with addition of the bacterial consortium within 75 days

Figure 3 (b) presents the variations of TPH concentrations during the bioremediation process. It should be noted that a significant change was not seen at the samples containing TPH contents higher than $3700 \mathrm{mg} / \mathrm{L}$, even though they were inoculated with the adapted consortium. On the other hand, in the case of the sample with the initial concentration of $600 \mathrm{mg} / \mathrm{L}$, a notable change was seen over the process time; as can be seen, an approximate $60 \%$ decrease happened in inoculated soil sample with the acclimatized consortium and only $14 \%$ in the uninoculated sample (control sample) over 75 days. Thus, based on the results obtained in the current research, it can be claimed that the concentration of the pollutant (TPHs) is a limiting factor because other environmental parameters were at the suitable range. For instance, in this study, since the soil was deficient in nitrogen and phosphorus, $\mathrm{NH}_{4} \mathrm{Cl}$ and $\mathrm{KH}_{2} \mathrm{PO}_{4}$ were added to obtain an initial $\mathrm{C} / \mathrm{N} / \mathrm{P}$ ratio of $100 / 10 / 1$, which is suitable for the growth of bacteria (Gargouri et al., 2012) and the $\mathrm{pH}$ value ranged between 6 and 8 during the bioremediation time. However, since our work was not a culture-based study and we utilized the actual samples of the soil instead of a synthetic soil sample, other variables like the presence of potentially toxic metals in soil may be effective in as much as it makes it impossible for bioremediation processes. In accordance with this claim, Gargouri et al. (Gargouri et al., 2014) reported a dramatically higher reduction in TPH during 70 days (96\%); of course, the initial concentration was approximately 65 $\mathrm{mg} / \mathrm{L}$, which is nearly ten times less than that of in our study.

Like previous studies (Kaplan and Kitts, 2004; Sutton et al., 2013), the bioremediation process occurred in two phases and much of degradation happened in the first stage (approximately $50 \%$ reduction in 45 days); the second phase, which was by far slower than the first one, reached only $10 \%$ degradation and then the removal efficiency leveled off. In the early stage of bioremediation, normal alkanes and low molecular weight aromatics are most sensitive to biodegraders (Venosa et al., 1997). It is worth noting that the control did not reach a notable TPH degradation even though it was provided the same conditions without inoculation. In accordance with our study, Liu et al. stated that a significant biodegradation happened during the first 35 days of the process (Liu et al., 2011) and then the rate of bioremediation declined.

The number of culturable bacteria of the sample soil ranged between 200 and $300 \mathrm{CFU} / \mathrm{g}$. It is believed that, if we want to have a significant bioremediation, the number of hydrocarbon-degrading bacteria should be more than $10^{5} \mathrm{CFU} / \mathrm{g}$ of soil (Mishra et al., 2001), otherwise it can act as a limiting factor ( $\mathrm{Xu}$ et al., 2014). At higher numbers of acclimatized petroleum degrading bacteria, their competition ability increases towards native microorganisms of soil (Xu et al., 2014). Therefore, in this research, the experiments were inoculated at the bacterial number of $10^{6} \mathrm{CFU} / \mathrm{g}$ (2 McFarland). As can be seen from figure $3(\mathrm{a})$, a decrease happened in the number of bacteria after the inoculation $\left(0.9 \times 10^{6} \mathrm{CFU} / \mathrm{g}\right)$ during the first 13 days, which may be owing to the lag phase of the strains; the data obtained from the investigation of growth rates of the bacteria confirm this claim. Similar results were reported by Mishra et al. (Mishra et al., 2001). This delay in biodegradation is due to the hydrophobic property of the materials in crude oil, which decrease the bioavailability of them to bacteria. Of course, after passing the lag phase, the polarity of the crude oil increases and then the bioavailability goes up (Xu et al., 2014). It was found that nearly all strains had rather a long lag phase. But, after this time, an increase was observed in the number of the bacteria and it reached $1.2 \times 10^{6} \mathrm{CFU} / \mathrm{g}$ on the day 20 and increased gradually by $1.4 \times 10^{6} \mathrm{CFU} / \mathrm{g}$ on the day 30 ; at this stage, in which the log phase occurred, the highest degradation rate was obtained. This illustrates that the isolated strains had been adapted to this soil because they were isolated from the sites with aged pollution with crude oil. Following, the number started to decline slowly and 
reached $0.5 \times 10^{5} \mathrm{CFU} / \mathrm{g}$. It should be pointed that the number of the uninoculated soil samples ranged from 200 to $450 \mathrm{CFU} / \mathrm{g}$.

In the current research, the enumeration of the bacteria in the consortium was proceeded after 90 days; a very important point to make here is that the number of CFU/g of soil became approximately zero. However, when a suspension of the soil was prepared and cultured in trypticase soy broth and then plated on nutrient agar, only the strain: Brevibacillus sp. could grow (according to the results of the biochemical tests (data not shown). It shows that this strain can survive and grow in a harsh environment polluted with crude oil. Ellipsoidal spores are formed by the Firmicute phylum (Logan and Vos, 2015); but strain 9, which is of the Firmicute phylum could not survive after four months. It is the first time that Brevibacillus is isolated from the petroleum contaminated soils and its survival in bioremediation is reported. Of course, further studies are needed to investigate more precise the tolerance and biodegradation potential of these strains separately and in full-scale applications.

\section{Conclusions}

It can be claimed that the acclimatized bacteria could remediate the contaminated soil. The bacteria selected for bioaugmentation had higher growth rates in a mineral salt culture containing $2 \%$ of crude oil than other strains. Moreover, when it comes to actual soil samples, the applied consortium could tolerate only the TPH concentrations up to $3700 \mathrm{mg} / \mathrm{L}$. Therefore, so as to purify full-scale pollutions, other than only bioaugmentation, other methods like biopile composting can be considered as better alternatives.

\section{Acknowledgments}

This project was backed by the Vice Chancellorship for Research Affairs of UMSHA (No. 9404021830). The authors are grateful to Hamadan University of Medical Sciences for providing research materials, equipment and fund. We are also grateful to the Iranian Oil Terminals Company (IOTC) for providing us with the soil samples.

\section{References}

Aljuboury D.D.A., Palaniandy P., Abdul Aziz H.B. and Feroz S. (2017), Treatment of petroleum wastewater by conventional and new technologies-A review, Global Nest Journal, 19, 439452.

Almasi A., Mosavi A., Mohammadi M., Azemnia S., Godini K., Zarei A., Mohammadi S. and Saleh E. (2016), Efficiency of integrated ultrasonic and anaerobic digestion of oil refinery wastewater sludge, Global Nest Journal, 18, 771-777.

Arvanitis N., Katsifas E.A., Chalkou K.I., Meintanis C. and Karagouni A.D. (2008), A refinery sludge deposition site: presence of nahH and alkJ genes and crude oil biodegradation ability of bacterial isolates, Biotechnol. Lett., 30, 2105-2110.

Bagherzadeh-Namazi A., Shojaosadati S. and Hashemi-Najafabadi S. (2008), Biodegradation of used engine oil using mixed and isolated cultures, Int J. Environ Res, 2, 431-440.

Couling N.R., Towell, M.G. and Semple, K.T. (2010), Biodegradation of PAHs in soil: influence of chemical structure, concentration and multiple amendment, Environ. Pollut., 158, 3411-3420.

Dibble J. and Bartha R. (1979), Effect of environmental parameters on the biodegradation of oil sludge, Appl. Environ. Microbiol., 37, 729-739.

El Aila N.A., Tency I., Claeys G., Saerens B., De Backer E., Temmerman M., Verhelst R. and Vaneechoutte M. (2009), Genotyping of Streptococcus agalactiae (group B streptococci) isolated from vaginal and rectal swabs of women at 35-37 weeks of pregnancy. BMC Infect. Dis., 9, 153.

El Mahdi A.M., Aziz H.A., Amr S.S.A., El-Gendy N.S. and Nassar H.N. (2016), Isolation and characterization of Pseudomonas sp. NAF1 and its application in biodegradation of crude oil, Environ. Earth. Sci., 75, 380.

Eriksson M., Dalhammar G. and Borg-Karlson A.-K. (1999), Aerobic degradation of a hydrocarbon mixture in natural uncontaminated potting soil by indigenous microorganisms at $20^{\circ} \mathrm{C}$ and $6{ }^{\circ} \mathrm{C}$, Appl. Microbiol. Biotechnol., 51, 532-535.

Fallgren P.H. and Jin S. (2008), Biodegradation of petroleum compounds in soil by a solid-phase circulating bioreactor with poultry manure amendments, J. Environ. Sci. Heal. A., 43, 125131.

Gargouri B., Aloui F. and Sayadi S. (2012), Reduction of petroleum hydrocarbons content from an engine oil refinery wastewater using a continuous stirred tank reactor monitored by spectrometry tools, J. Chem. Technol. Biotechnol., 87, 238243.

Gargouri B., Karray F., Mhiri N., Aloui F. and Sayadi S. (2014), Bioremediation of petroleum hydrocarbons-contaminated soil by bacterial consortium isolated from an industrial wastewater treatment plant, J. Chem. Technol. Biotechnol., 89, 978-987.

Ghazali F.M., Rahman R.N.Z.A., Salleh A.B. and Basri M. (2004), Biodegradation of hydrocarbons in soil by microbial consortium, Int. Biodeterior. Biodegradation, 54, 61-67.

Horowitz A., Gutnick D. and Rosenberg E. (1975), Sequential growth of bacteria on crude oil, Appl. Microbiol. Biotechnol., 30, 10-19.

Kaplan C.W. and Kitts C.L. (2004), Bacterial succession in a petroleum land treatment unit, Appl. Environ. Microbiol., 70, 1777-1786.

Koolivand A., Rajaei M.S., Ghanadzadeh M.J., Saeedi R., Abtahi H. and Godini K. (2017), Bioremediation of storage tank bottom sludge by using a two-stage composting system: Effect of mixing ratio and nutrients addition, Bioresour. Technol., 235, 240-249.

Lal B. and Khanna S. (1996), Degradation of crude oil by Acinetobacter calcoaceticus and Alcaligenes odorans, J. Appl. Microbiol., 81, 355-362.

Liu P.-W.G., Chang T.C., Whang L.-M., Kao C.-H., Pan P.-T. and Cheng S.-S. (2011), Bioremediation of petroleum hydrocarbon contaminated soil: effects of strategies and microbial community shift, Int. Biodeterior. Biodegradation, 65, 11191127.

Logan N.A. and Vos P.D. (2015), Brevibacillus. Bergey's Manual of Systematics of Archaea and Bacteria, John Wiley \& Sons, Ltd.

Mishra S., Jyot J., Kuhad R.C. and Lal B. (2001), In situ bioremediation potential of an oily sludge-degrading bacterial consortium, Curr. Microbiol., 43, 328-335.

Nnamchi C., Obeta J. and Ezeogu L. (2006), Isolation and characterization of some polycyclic aromatic hydrocarbon 
degrading bacteria from Nsukka soils in Nigeria, Int. J. Environ. Sci. Technol., 3, 181-190.

Ornston L.N. and Yeh W.-K. (1982), Recurring themes and repeated sequences in metabolic evolution, Biodegradation and Detoxification of Environmental Pollutants, CRC Press, Miami.

Poi G., Aburto-Medina A., Mok P.C., Ball A.S. and Shahsavari E. (2017), Large scale bioaugmentation of soil contaminated with petroleum hydrocarbons using a mixed microbial consortium, Ecological engineering., 102, 64-71.

Rahman K., Thahira-Rahman J., Lakshmanaperumalsamy P. and Banat I. (2002), Towards efficient crude oil degradation by a mixed bacterial consortium, Bioresour. Technol., 85, 257-261.

Ramos J., Duque E. and Ramos-Gonzalez M. (1991), Survival in soils of an herbicide-resistant Pseudomonas putida strain bearing a recombinant TOL plasmid, Appl. Environ. Microbiol, 57, 260-266.

Song H.-G., Wang X. and Bartha R. (1990), Bioremediation potential of terrestrial fuel spills, Appl. Environ. Microbiol., 56, 652-656.

Sutton N.B., Maphosa F., Morillo J.A., Al-SoUD W.A., Langenhoff A.A., Grotenhuis T., Rijnaarts H.H. and Smidt H. (2013), Impact of long-term diesel contamination on soil microbial community structure, Appl. Environ. Microbiol., 79, 619-630.

Timmis K.N., Mcgenity T., Van Der Meer J.R. and De Lorenzo V. (2010), Handbook of hydrocarbon and lipid microbiology, Springer Berlin.

Venosa A., Suidan M., King D. and Wrenn B. (1997), Use of hopane as a conservative biomarker for monitoring the bioremediation effectiveness of crude oil contaminating a sandy beach, J. Ind. Microbiol. Biotechnol., 18, 131-139.

Whyte L.G., Greer C.W. and Inniss W.E. (1996), Assessment of the biodegradation potential of psychrotrophic microorganisms, Can. J. Microbiol., 42, 99-106.

Wilke B.-M. (2005), Determination of chemical and physical soil properties, Monitoring and Assessing Soil Bioremediation, Springer.

Xu J., Deng H., Huang T. and Song S. (2014), Enhanced biodegradation of crude oil in contaminated soil by inoculation of hydrocarbon-degraders, Desalin. Water. Treat., 52, 5126-5135. 